Article

\title{
New Urbanism: Past, Present, and Future
}

\author{
Ajay Garde \\ Department of Urban Planning and Public Policy, University of California at Irvine, Irvine, CA 92697-7075, USA; \\ E-Mail: agarde@uci.edu
}

Submitted: 13 July 2020 | Accepted: 16 October 2020 | Published: 22 December 2020

\begin{abstract}
The New Urbanism, initially conceived as an anti-sprawl reform movement, evolved into a new paradigm in urban design. Recently, however, some researchers have argued that the popular appeal of New Urbanism has eroded, the movement has lost its significance, and critical research on the broader theme has tapered off. In response, this article investigates whether the movement has lost its currency and explores the future of New Urbanism in the context of contemporary circumstances of development. The article begins with a brief description of the conceptualization of New Urbanism as an exception to the development trends of the time. Collaborative efforts of its protagonists that have contributed to the integration of New Urbanist concepts into other programs, policies, and development regulations are presented in the next section to describe its expansion, to clarify its mainstreaming, and to call attention to its broader impact. The concluding section presents contemporary circumstances of development and changes that are intensified by the COVID-19 pandemic, including those related to the nation's demographics, climate change, technological advances, rapid growth of the digital economy, and acceleration of e-commerce to explore the significance of New Urbanism for future development.
\end{abstract}

\section{Keywords}

COVID-19; New Urbanism; sustainable growth; urban and suburban development

\section{Issue}

This article is part of the issue "New Urbanism: From Exception to Norm-The Evolution of a Global Movement" edited by Susan Moore (University College London, UK) and Dan Trudeau (Macalester College, USA).

(C) 2020 by the author; licensee Cogitatio (Lisbon, Portugal). This article is licensed under a Creative Commons Attribution 4.0 International License (CC BY).

\section{Introduction}

The theme of New Urbanism, initially conceived as an anti-sprawl reform movement, evolved into a new paradigm in urban design. The promotion of the physical design concepts of New Urbanism started in the 1980s with the development of the Seaside residential lots in Walton County, Florida. In the 1990s, the planning and design principles established during the first three meetings of the Congress for the New Urbanism (CNU) became widely popular. These physical design principles, articulated for development at several scales from the region to the block and street, were formulated to address the problems and related urban experiences of the time and distinguished the New Urbanist movement and the types of projects it promoted as an exception to the norm. At the time, most conventional development projects produced low-density, use- segregated development that intensified automobiledependency, and exacerbated sprawl. In contrast, New Urbanist projects were expected to promote mixed-use, mixed-income, compact developments that integrated a variety of housing types and supported alternative modes of transportation.

New Urbanist designers conceived these projects as a response to the social and spatial segregation of the population by race and income, the deteriorating environmental quality, a declining public realm, and the growth of non-place edge-city phenomena characterized as sprawl. Developers and sponsors promoted these projects to stimulate social and economic diversity and to engender an enhanced sense of community in urban and suburban developments. City planners and elected official endorsed these projects as sustainable growth. Starting in the 1990s, New Urbanist projects proliferated in several municipalities across the United States and 
were supported by institutional and regulatory reforms, taking the form of suburban green-field developments, urban in-fill projects, and urban transit-oriented developments (Calthorpe \& Fulton, 2001; CNU, 2004; Duany \& Plater-Zyberk, 1991). In addition, planners and urban designers in Britain, Canada, France, India, Indonesia, Japan, Scotland, and Turkey were inspired by the physical design principles of New Urbanism and used these concepts to design the built environment (Steuteville, 1998).

Over time, the planning and design concepts of New Urbanism gained wider popularity, became diffused into development trends, and considerably influenced public policy (Steuteville, 1998; Talen, 2005). The movement also inspired a number of derivative planning and design concepts including smart growth, healthy cities, and transit-oriented communities that expanded the debate on compact development vis-à-vis sprawl. In addition, collaborative efforts of the CNU have contributed to the development of the Leadership in Energy and Environmental Design for Neighborhood Design, commonly known as the LEED-ND rating system (U.S. Green Building Council [USGBC], 2007). The LEED-ND rating system is considered an industry standard and is used for evaluating the sustainability of neighborhood-scale projects. Furthermore, New Urbanist designers have contributed to the formulation and promotion of formbased zoning codes that focus more on physical form and less on land use to regulate new development. Several cities and counties in the United States have already adopted, or are adopting, form-based codes to facilitate sustainable growth and to achieve a variety of objectives (Garde \& Kim, 2017). Taken together, the diffusion of New Urbanist concepts into development projects, policies, and regulations signifies New Urbanism's evolution from an exception to the norm to an established paradigm in planning and urban design, which is referred to as its move from 'the fringe to the center' in this thematic issue.

There is substantial literature on New Urbanism. A significant proportion of the literature concerns the ideas and ideals of the New Urbanism (Duany \& Plater-Zyberk, 1991; Ellis, 2002; Ewing et al., 2013a; Forsyth, 2015; Fulton, 1996; Passell, 2013). In addition, there is literature evaluating the social and spatial dimensions of New Urbanist projects vis-à-vis sprawl, social construction of New Urbanism, critiques of New Urbanism as a new paradigm in urban design, and on the expected benefits of New Urbanist projects (Day, 2003; Talen, 2005). Advocates of New Urbanism have emphasized the role of physical design in addressing a number of socio-spatial problems from the initial stage of its conceptualization and diffusion. In particular, they have emphasized that physical design can be used to address the segregation of population by race and income, to encourage a sense of community among its residents, as well to mitigate placelessness (CNU, n.d.; Talen, 1999).

Critics, however, have questioned the New Urbanist emphasis on physical design to achieve social objec- tives. Southworth (1997) argued that the development of walkable neighborhoods in sprawling regions may not reduce the dependence on automobile. Robbins (1998) pointed out that a sense of community can be encouraged through social programs and engagement with the residents; however, it cannot be designed. Grant (2006) stated that while the movement has succeeded in reviving the debate on how to design a good community, social justice issues are sometimes overlooked. Garde (2004) pointed out that while many New Urbanist projects include a variety of housing types, not all projects include affordable housing. Some researchers have questioned whether the theme of small village model, neo-traditional layout, and architectural style of New Urbanist projects is concocted as a postmodernist palliative to modern problems (Audirac \& Shermyen, 1994). Others have argued that most of these projects cater to high-income households who self-select themselves into these neighborhoods (Grant, 2007; Harvey, 1997; Hirt, 2009).

A significant proportion of the literature on New Urbanism had initially focused narrowly on some very specific and idiosyncratic themes and practices of the paradigm marginalizing its larger impact and broader implications. Talen (2019) has observed that these critiques of New Urbanism do not offer practical alternatives to conventional suburban developments that lead to sprawl. The critiques of New Urbanism, and the rebuttals, have been reviewed in considerable detail by Ellis (2002). In addition, some researchers have pointed to potential benefits of New Urbanist type compact, mixed-use, urban infill, and transitoriented developments that include a variety in types of housing and, in particular, affordable housing in neighborhood-scale projects. These benefits include reduced vehicle miles traveled (VMT); increased transportation choices, especially for a transit-dependent population; increased transit ridership; increased household disposable income from the use of public transit; increased local economic development; reduced air pollution and energy consumption; and reduced local infrastructure costs (Boarnet, 2011; Boarnet, Forsyth, Day, \& Oaks, 2011; Cervero \& Kockelman, 1997; Ellis, 2002; Garde, 2006; Moore, 2013; Schlossberg \& Brown, 2004; Trudeau, 2016).

New urbanist type projects face considerable regulatory and non-regulatory barriers, however. Existing land development regulations restrict higher-density developments and non-regulatory barriers-such as the high cost and limited availability of land for development near transit stations, regulatory requirements for inclusion of affordable housing units into projects as well as lack of incentives for including affordable units into housing projects, local concerns for displacement and loss of sense of community that contributes to 'Not in My Back Yard' opposition to projects-remain as major barriers even when development regulations are modified to permit projects with higher densities (Garde, 2019). 
In recent years, researchers also have evaluated the integration of New Urbanist design concepts in development regulations and into sustainability rating systems, and have identified the need to conduct research that goes beyond the debate on New Urbanist principles and focuses on the challenges to their implementation (Garde, 2009; Garde \& Kim, 2017; Talen, 2019).

Some researchers, however, have suggested that the popular appeal of New Urbanism has eroded in recent years and that there seems to be a lack of interest in academic and professional circles in conducting critical research on the topic, which is also a premise explored further in this thematic issue of the journal. In particular, Fulton (2017, para. 4) argues that New Urbanism has become so mainstream that it has lost its appeal as a distinct movement and that it is no longer a "big deal." There is no doubt that New Urbanist-type projects are no longer perceived as atypical by most city planners and a significant proportion of neighborhood-scale housing projects in fast-growing regions across the United States are designed as compact, walkable, and mixed-use developments (Garde, 2008). In addition, it is clear that the circumstances of urban development have changed considerably since the conceptualization of New Urbanism in the 1990s when Baby Boomers were the largest living adult generation in the nation. But does this mean that the theme of New Urbanism has lost its currency? Furthermore, what is the future of New Urbanism in the context of the contemporary circumstances of urban development that are very different from when it was initially conceived, and the COVID-19 crisis, which has accelerated the changes that have been underway for some time? Talen (2019) explains that throughout the 1990s the advocates of the movement made a conscious effort to make the New Urbanism mainstream. She adds that some prominent researchers were initially skeptical of value of New Urbanism at the time; however, we have turned the corner and the debate on New Urbanism now focuses on barriers to implementing the normative ideals of the movement and not on its relevance to the field.

An exploration of the future of New Urbanism requires a retrospective view of the problems and circumstances of urban and suburban development that contributed to its innovation as an anti-sprawl movement. In addition, an investigation of New Urbanism would benefit from a discussion of its impact and how the collaborative efforts of its advocates have led to the integration of its design principles into sustainability rating systems, zoning regulations, and land development policies adopted at the local, regional, and state levels. Finally, a consideration of the future of $\mathrm{New}$ Urbanism necessitates a review of the present-day circumstances of urban development that are characterized by a number of interrelated trends that have been underway for some time. These trends include important and interrelated changes including those related to the nation's demographics; climate change; technological advances; remote work; restructuring of the global economy, including rapid growth of the digital economy; and acceleration of e-commerce and what is known as the 'Amazon effect,' some of which are intensified by the COVID-19 pandemic (Garde, 2019). Cities across the United States already face major challenges presented by these changes and will need to address them in the planning for the future of their jurisdictions. The future of New Urbanism is likely to be shaped by its strengths and weaknesses in addressing these challenges as discussed below.

It is important to note that while New Urbanism has influenced the design and development of new projects in several countries, it has had the greatest impact on the development of projects, policies, and regulations in the United States, as compared to other countries. With this in mind, the article describes the evolution of the movement and explores the future of New Urbanism in the United States. Consequently, the generalizability of the ideas and conclusions presented in this article is limited to the United States.

The remainder of the article is organized into four sections. In Section 2, I discuss the origins and the conceptualization of New Urbanism as a reform movement, emphasizing physical design as a tool for improving the quality of life in urban and suburban areas. In Section 3, I discuss the impact of New Urbanism on urban development trends as well as the collaborative efforts of its protagonists that have contributed to the integration of New Urbanist concepts into other programs, policies, and development regulations to describe its expansion, to clarify its mainstreaming, and to underscore its broader impact. In the same section, I discuss how the New Urbanist movement and the design ideas that it promotes have been supported by various forms of institutional endorsements and regulatory reforms. In Section 4, I discuss the changing circumstances of urban development in the context of COVID-19 pandemic and explain the challenges that cities are already facing to explore the future of New Urbanism. In Section 5, I present the conclusions.

\section{The Past: Conceptualization of New Urbanism}

In a 1999 personal interview with the author, Robert Davis, the developer of Seaside, stated that he asked Andres Duany and Elizabeth Plater-Zyberk, founding members of the New Urbanist movement based in Miami, Florida, to help him develop Seaside as a walkable small town similar in structure and architecture to older seaside towns in the Southern United States and in the Mediterranean that he had visited during his travels. Seaside is considered one of the earliest New Urbanist projects, and, although developed as a resort, some of the planning and design ideas used in the project and later promoted through the movement became widely popular and gained currency in academic and professional circles. It is noteworthy that the design of Seaside was based on a form-based code that relied on a typology of 
buildings and a regulating plan that assigned each type of development to specific areas of the site.

Laguna West, another well-known New Urbanist project, designed by Peter Calthorpe, one of the founding members of the movement, became a reality for very different reasons. Delsohn (1994) noted that Calthorpe's opportunity to integrate his design concepts into a project came to him in 1989, when he met Phil Angelides during a symposium titled Towards a New Suburbia that he, Duany, and Solomon had organized at the University of California, Berkeley. Angelides was a candidate for state treasurer at the time and was developing Laguna West in Sacramento County. Laguna West was initially designed and approved as a standard subdivision with cul-de-sacs, but Angelides wanted to avoid a development record that could be seen as contributing to the traffic and environmental problems and that could weaken his candidacy. Angelides attended the Berkeley conference at the suggestion of the members of the Environmental Council of Sacramento, who had sued another large suburban subdivision in the region. When Calthorpe came on board, the design of Laguna West was significantly transformed from a conventional suburban subdivision to a modified version of 'pedestrian pockets.'

Several New Urbanist concepts were initially identified by specific terms used by individual architects and urban designers to refer to physical design principles that they had used in their projects (Fulton, 1996; Katz, 1994). For instance, 'traditional neighborhood development' and 'neo-traditionalism' are terms used by the office of Duany Plater-Zyberk \& Associates. In a similar manner, terms such as 'transit-oriented development' and 'pedestrian pockets' are used by Calthorpe Associates. Later, these diverse but interrelated sets of ideas were integrated into a broader theme of New Urbanism. Passell (2013) explains that the term New Urbanism was coined in a discussion between Stefanos Polyzoides and Peter Katz in 1991 while they were trying to identify an appealing title for Katz's book that would also be apropos for the movement. Later, a meeting was convened by California's Local Government Commission at the Ahwahnee Hotel at Yosemite National Park in California to propose a set of design principles for promoting sustainable and livable cities. The meeting, which included Andres Duany, Elizabeth Plater-Zyberk, Peter Calthorpe, Stefanos Polyzoides, and other founding members of the New Urbanism, except Daniel Solomon, led to the articulation and endorsement of what is known as the Ahwahnee Principles to address the problems of development of the time.

The Ahwahnee meeting also laid the foundation for the establishment of the $\mathrm{CNU}$, an advocacy group formed in October 1993 (Katz, 1994). CNU provided the impetus for the movement by convening annual meetings and articulated a set of design principles that were developed into what is known as the Charter of the New Urbanism. The Charter was given its current form during the first three meetings organized between 1993 and 1995 (CNU, n.d.). Advocates of New Urbanism presented a set of physical design ideas, from neighborhood scale to regional scale, to mitigate sprawl and to encourage sustainable growth sensitive to environmental quality, economy, and social equity (Calthorpe, 1993; Duany \& Plater-Zyberk, 1991; Garde, 2004; Talen, 2005). Typical New Urbanist projects were expected to include an interconnected network of streets and blocks organized around a neighborhood center, a mix of land uses, a variety of housing types and densities to create a compact urban form, and a pedestrian-oriented design with an emphasis on providing civic spaces and amenities within walking distance (Steuteville, 1998).

Planning and design concepts developed during the first three CNU meetings influenced the institutional reforms that started in the mid-1990s. This was reflected in the land use and architectural design guidelines for the neo-traditional developments included in the Architectural Graphic Standards published by the American Institute of Architects in 1994 as well as in street design guidelines for the traditional neighborhood developments published by the Institute of Transportation Engineers (ITE) in 1997. The New Urbanist movement was bolstered when Henry Cisneros, Secretary of the U.S. Department of Housing and Urban Development (HUD) at the time, initiated a 'Homeownership Zones' program that offered grants and loans to cities for redevelopment based on New Urbanist principles. HUD also launched a program, HOPE VI, to redevelop severely distressed public housing in cities across the nation (CNU, n.d.). Several cities and counties in the United States endorsed New Urbanist design schemes and facilitated projects that promoted principles of New Urbanism to engender an improved quality of life and to address the problems associated with postWorld War II patterns of urban and suburban development (Garde, 2004).

\section{The Present: Expansion of New Urbanism}

In recent years, CNU has expanded its focus to more explicitly address environmental as well as socioeconomic problems, and has collaborated with other organizations to promote the integration of New Urbanist ideas in sustainability rating systems, development policies, and regulations. In particular, a collaboration among CNU, the Natural Resources Defense Council, and the USGBC has led to the development of the LEED-ND rating system (USGBC, 2007). LEED-ND is a voluntary and marketdriven rating system that professionals have used to evaluate and certify the sustainability of neighborhood-scale projects. According to USGBC (2007, p. 1), the LEED-ND rating system promotes sustainability of projects by improving energy and water efficiency and serves to "revitalize existing urban areas, reduce land consumption, reduce automobile dependence, promote pedestrian activity, improve air quality, decrease polluted stormwater runoff, and build more livable, sustainable 
communities for people of all income levels." It is important to note that the construction of new housing had reduced significantly in the wake of global financial crisis in 2009, which initially may have had a negative impact on the trajectory of LEED-ND certified projects as well as New Urbanist projects. However, it is expected that the diffusion of the sustainability concepts of the LEED-ND rating system into the development industry will contribute to the promotion of sustainable design concepts in housing projects (Smart Growth Network, 2006; U.S. Environmental Protection Agency [EPA], n.d.; USGBC, 2007). Researchers also have estimated that LEED-ND projects in urban and central locations have the potential to significantly reduce vehicles miles of travel of their residents (Ewing, Greenwald, Zhang, Bogaerts, \& Greene, 2013b). Several cities in the United States have encouraged the integration of sustainability criteria included in the LEED-ND rating system into projects. Some cities have provided financial and regulatory incentives to encourage LEED-ND certified projects in their jurisdiction (Garde, 2009).

More recently, CNU members have contributed to the development and dissemination of form-based codes that focus more on physical form and less on segregation of land uses to regulate development as compared to conventional zoning codes (Parolek, Parolek, \& Crawford, 2008). Several cities and counties across the United States have adopted form-based codes to replace conventional zoning codes for specific areas of the city or for an entire city (Garde \& Kim, 2017). Form-based codes received a significant boost when then-Governor Arnold Schwarzenegger of California signed Assembly Bill 1268 into law in 2004, which authorized local governments to adopt form-based codes instead of conventional zoning codes. In addition, CNU advocated for revising the regulations related to increasing the proportion of commercial areas allowed in mixed-use buildings, which led the Federal Housing Administration to change the rules that now permit condominiums in mixed-use buildings with commercial areas of up to 35 percent, a 10 percent increase from the limit (CNU, n.d.; Gose, 2012).

In 2017, CNU collaborated with the ITE to jointly produce the report Implementing Context-Sensitive Design on Multimodal Corridors: A Practitioner's Handbook that transportation engineers and planners can use to design multimodal transportation corridors within the broader context of community objectives, street networks, and land uses in the area (CNU, n.d.; ITE, 2017). The CNU (2018) also adopted a statement that highlighted its commitment to support more inclusionary development practices.

Furthermore, the New Urbanist movement has helped to inspire a number of planning and design concepts, including smart growth, aimed at mitigating sprawl, and health districts, aimed at removing the barriers between urban neighborhoods and health systems (CNU, n.d.; EPA, n.d.). The diffusion of New Urbanist design ideas into development practices is also evident in recent research as well as in reports on real estate trends and development practices (Garde, 2009; ITE, 2017; Moore, 2013; Talen, 2019). A survey of senior city planners in all 180 cities in the five-county Southern California region, which examined the physical design characteristics of neighborhood-scale projects in their cities, indicates that a significant proportion of new projects built or under construction around the turn of the millennium were mixed-use, high-density, compact developments that integrated some of the physical design concepts also promoted by New Urbanism (Garde, 2008). Taken together, the diffusion of New Urbanist concepts into development projects, policies, and regulations signifies New Urbanism's evolution from an exception to the norm to a resilient and well-established paradigm in the fields of planning and urban design.

\section{The Future: New Challenges and New Urbanism}

From its earliest stage, New Urbanism was conceived and promoted as an anti-sprawl movement that emphasized compact, higher-density, mixed-use development that is less land consumptive, less auto-dependent, and generally more sustainable than is low-density development. Over time, New Urbanism evolved as a new paradigm in the fields of planning and urban design. The circumstances of development in the United States also have changed considerably in the four decades since its inception, however. These circumstances of development are characterized by interrelated trends that have important implications for the future of New Urbanism even though the specific ways in which we might expect to see changes in the design of New Urbanist projects are not that clear at this time.

The future of New Urbanism will be defined, in part, by how the debate on density unfolds and by the preferences of the Millennials in terms of where they will choose to live, work, shop, and play. The spread of the COVID-19 pandemic and the recommendations from public health officials to maintain social distance to slow the spread of the virus have led to speculation about how higher-density urban environments and commuting to work on mass transit may contribute to the spread of the infection, which has reignited the debate on the compact development versus sprawl (Badger, 2020). Compact and higher-density development, sometimes referred to as density, is frequently equated with overcrowding by advocates of low-density development as well as by sponsors of slow growth or no growth in cities. Andrew Cuomo, governor of the state of New York, has linked New York City's considerably high number of COVID-19 cases to its high-density built environment and mass transit, arguing that "dense environments are its feeding grounds" although other high-density cities, such as Hong Kong, Seoul, and Tokyo have had a much smaller proportion of cases (Dillon, 2020). In an op-ed column in the Los Angeles Times, Joel Kotkin (2020) contends that Los Angeles and its low-density suburbs have had 
comparatively fewer cases of infection and death related to COVID-19 pandemic than the dense and transitdependent New York City.

However, cases of COVID-19 infection and death have increased considerably, in Los Angeles and its suburbs, within weeks since the publication of the column. Indeed, recent research indicates that the pandemic is spreading in low-density communities across the nation (Payton, 2020; The New York Times, 2020). It is also noteworthy that many European cities with relatively higher-density built environment and extensive public transportation network have considerably lower infection rates than cities in the United States (World Health Organization, n.d.). The spread of COVID-19 has made people apprehensive of higher-density built environments and public transit; however, recent research focusing on COVID-19 infection and mortality rates suggests that crowding, not residential density (housing units per acre), is associated with the spread of the virus (Hamidi, Sabouri, \& Ewing, 2020).

Further, recent demographic changes pose new challenges as well as opportunities for development and have considerable implications for the future of New Urbanism. Urban and suburban development patterns are shaped, in part, by the demographic trends of the time. Duany (personal communication, 1999) noted that "it is the Baby Boomers' ethos that will be the dominant ethos until 2030 because the nation is going to be dominated by the Baby Boomers." Indeed, the broader theme of New Urbanism was conceived to address the values of Baby Boomers, with particular attention to where they preferred to live, work, shop, and play. Much has changed, however, in the last three decades. Millennials have now replaced Baby Boomers as the largest living adult generation in the nation, which is contributing to current patterns of urban growth (Fry, 2020; Myers, 2016).

Recent population estimates point to the growing population of young minorities and the aging and declining population of white non-Hispanics in the nation (U.S. Census Bureau, 2017). Moreover, although some urban areas are experiencing substantial population growth, many Americans are moving to the suburbs due to unaffordable housing prices in cities (Frey, 2018). Further, Millennials, especially those who are minorities and new immigrants, have a preference for living in the denser, urban cores of large metropolitan areas as compared to suburbs (Frey, 2018). Currently, however, there is a substantial shortage of housing that has contributed to a housing affordability crisis in cities with strong job growth (Garde \& Kim, 2017). The stock of housing has not kept pace with population growth. Myers (2016) has argued that cities will have to compete with suburbs to attract and retain Millennials who are considering a move to the suburbs. Already, the accelerated rate of telecommuting and the shift to remote working during the COVID-19 pandemic may have made urban density and mass transit less appealing to a significant proportion of the Millennials. The debate on density is likely to continue in the post-COVID-19 world given the preferences of the Millennials, housing affordability crisis in cities with strong job growth, and regulatory barriers to higher-density development, and also because the debate is characterized by the ideological position of researchers, which rarely change. In this context, collaborative efforts of protagonists that have contributed to the development and promotion of form-based-codes that are already implemented by cities to permit, by right, compact, mixed-use, mixedincome developments that support alternative modes of transportation will favor New Urbanist type projects. Further, New Urbanist projects in suburbs aimed at retrofitting town centers and greyfields may offer alternatives to Millennials seeking transit accessibility, density, and amenities of urban cores of large metropolitan areas but are priced out of those areas.

There is, furthermore, an acute shortage of housing in some regions across the nation that can only be addressed by higher-density development because there is limited vacant land available for development. The five-county Southern California region is a case in point. The region has a considerable shortage of all types of housing and an acute shortage of low-income housing while the population is expected to continue to grow in the next decade. Further, most cities in the region have limited vacant land available for new development and cannot address their regional housing needs, as is required by state law, without changing zoning regulations and facilitating mixed-use and higher-density development. In California, state law also requires Metropolitan Planning Organizations to guide local policies to achieve sustainable development in their regions through an integrated approach to landuse planning, housing, and transit (Southern California Association of Governments, 2020). This in turn requires cities in Southern California to facilitate infill, mixedincome, mixed-use, higher-density developments that include a variety of housing types and support alternative modes of transportation, such as public transit, walking, and biking. It is expected that most new housing developments in the region are likely to be New Urbanist type compact, mixed-use, higher-density projects that are transit-supported and facilitate alternative modes of transportation such as walking and biking. Given this, at least in fast growing regions, the Millennials will most likely choose from limited options of housing that might be available to them.

The future of New Urbanism also will be defined by its contributions to mitigating climate change. Although sustainable design and development has been an almost continuous theme in the fields of urban planning and design, the urgency to address climate change has contributed to the adoption of certain measures by local and state governments in recent years. There is some evidence that low-density sprawl, with its auto-dependent development patterns, contributes to climate change, in 
part, due to increased VMT and associated greenhouse gas (GHG) emissions from low-occupancy passenger vehicles (California Air Resources Board, n.d.; Ewing et al., 2013a). Recent research, however, shows that the lockdowns and stay-at-home orders activated in many municipalities to slow spread of COVID-19 virus have significantly reduced the GHG emissions associated with VMT (Carlton, 2020; Gardiner, 2020). Recently, several environmental pollution prevention regulations and policies adopted during the Obama administration already have been dismantled or reversed, and there is a possibility that the reduced level of air pollution could lead to lax enforcement of existing pollution regulations.

The results of a study based on data on COVID-19related deaths from more than 3,000 counties in the nation highlight the importance of enforcing existing air pollution regulations to protect human health and the environment during and after the COVID-19 pandemic (Wu, Nethery, Sabath, Braun, \& Dominici, 2020). New Urbanist projects, especially those that are in-fill, higherdensity, mixed-use, and transit-oriented developments, are expected to reduce VMT and the number of vehicle trips. Such projects in existing transit-served areas, however, face considerable regulatory and non-regulatory barriers. Protagonists of New Urbanism have, for a long time, engaged in advocacy at local and state levels to remove regulatory and non-regulatory barriers to mixeduse, compact development to mitigate climate change. Stronger evidence is needed, however, to support the claims of climate mitigation and GHG emission reduction through New Urbanist design principles.

We have been witnessing major technological changes that have important implications for the future of New Urbanism. How we think about the design of neighborhoods and cities in the post-COVID-19 world will be shaped, in part, by electric vehicles, connected and autonomous vehicles, delivery robots, e-bikes and e-scooters, and the idea of shared-use mobility. Connected and autonomous and vehicles that use wireless technology to communicate with other vehicles and traffic signals, and that can be driven without human intervention, can improve the safety and mobility of young adults, seniors, and people with disabilities, but it will require us to rethink street configurations, parking requirements, and the transportation infrastructure in the post-COVID-19 world (Garde, 2019; Nelson, 2018; Rouse, Henaghan, Coyner, Nisenson, \& Jordan, 2018). Before the COVID-19 pandemic, it was anticipated that autonomous vehicles also could boost the use of public transit by providing better connectivity to transit stops, especially for the first and last miles, and improve the mobility of the transit-dependent population. Mass transit, however, may seem less appealing in the postCOVID-19 world, especially to those commuters who currently do not use public transit and would like to avoid it to maintain social distance in view of asymptomatic and silent spreaders of the virus. Indeed, if a significant proportion of commuters who currently use public transit shift to connected and autonomous vehicles, it will increase congestion on high-volume routes in cities (Henaghan \& Rouse, 2018; Nisenson, 2018).

Furthermore, delivery robots that deliver food, groceries, and parcels already are being used in some cities, where they are permitted to travel on certain streets and sidewalks (Garde, 2019). The author has, on several occasions, shared a sidewalk with a delivery robot and witnessed the delivery of pizza to customers (see Figure 1 for a photo of delivery robots). The transportation planning models typically used for predicting demand will not be very useful in the context of connected and autonomous vehicles and delivery robots sharing the streets and sidewalks with other vehicles and pedestrians in cities (Marshall, 2019). In this context, CNU's collaborative efforts with ITE to propose solutions for context-sensitive design of multi-modal transportation corridors could provide much needed insight (ITE, 2017).

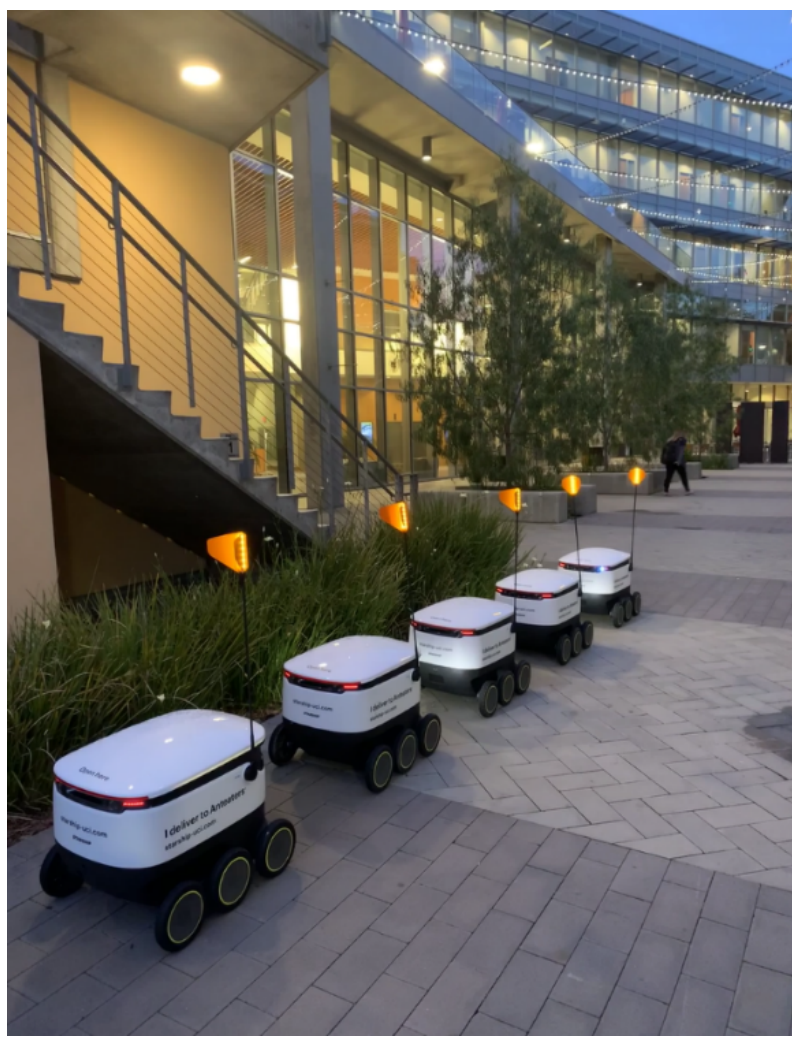

Figure 1. Delivery robots. Source: Author.

Although a larger restructuring of the global economy, stimulated by e-commerce, has been underway for some time, the COVID-19 pandemic has contributed to an unanticipated acceleration of e-commerce that will intensify some of the existing problems of development in cities but also offer new opportunities for addressing some of the problems. Even before the COVID-19 pandemic, online shopping had led to substantial growth in technology-driven e-commerce companies, such as Amazon, which was contributing to reduced profit margins for brick-and-mortar stores and shopping malls (Franck, 2018; Hartung, 2017). This trend, which 
is also known as the 'Amazon effect,' has intensified during the COVID-19 era and is expected to further accelerate the decline of small brick-and-mortar stores, large department stores, and shopping malls, some of which are already closing (Grosman, 2018; Irvine, 2020; Maheshwari, 2020; Sanburn, 2018). The bankruptcy filing by Neiman Marcus during the COVID-19 crisis is a case in point (Bhattarai, 2020).

Many brick-and-mortar stores, however, will survive, indeed thrive, by making their goods and services more appealing to local clientele, and not all shopping malls will close, but e-commerce is here to stay, and its impact is more likely to increase in the post-COVID-19 era. This, in turn, offers an opportunity for adaptive reuse of closed department stores and shopping malls, especially in cities with a shortage of vacant land available for housing and severe shortage of all types of housing, including affordable housing. New Urbanist designers could benefit from this opportunity for redevelopment and/or adaptive reuse of vacated commercial properties, including shopping malls and department stores for developing projects that also include affordable housing.

It is reasonable to expect that e-commerce will influence the design of New Urbanist projects that are conceived as mixed-use developments. Thus, New Urbanist projects will need to include a carefully calibrated and finer-grain mix of commercial uses such as coffee shop, ice cream parlor, juice bar, internet café, hair salon, and the like that cater to local needs and are difficult to fulfill through e-commerce. The redevelopment and/or adaptive reuse of vacated commercial properties offers an opportunity to include what Oldenburg (1989) has called "third places" in New Urbanist projects. However, the extent to which these third places may be included in New Urbanist projects will depend on their urban (or suburban) location, the demand for different types of housing, and the availability of land for development.

In like manner, as the idea of remote work gains more acceptance and more people work from home, it would be reasonable to expect that this in turn may reduce the overall need for office space; however, the consumption standards per person for office space may increase in the short term until a vaccine for the coronavirus is available. It is too early to tell whether the need for office space will reduce in the long term, given our fundamental need for social contact especially in office settings where people spend most of their waking hours and it is difficult to anticipate how the future demand for office space will change New Urbanist projects.

\section{Conclusion}

It is clear that there are some fundamental shifts underway that are related to the nation's changing demographics, climate change, technological advances and remote work, as well as e-commerce and rapid growth of the digital economy, some of which have been intensified by the COVID-19 pandemic. However, the ways in which we might expect to see changes in the design of New Urbanist projects are not that clear, as discussed above.

There is ample evidence that critical research on New Urbanism has continued, albeit without the label, as the debate has shifted from New Urbanist ideas and ideals to its various and differentiated forms. Recent research has highlighted the need to evaluate the relationship between New Urbanist design and environmental outcomes (Turner, 2019); pointed out the need to promote racial diversity and inclusion through New Urbanist projects (Jackson, 2019); emphasized the need to examine the relationship between retail revitalization in cities and gentrification (Kickert, 2019); explored theoretical foundations of New Urbanism (Ellis, 2019); studied the diffusion of New Urbanist design concepts in development regulations (Garde \& Kim, 2017); noted the need to measure social, economic, and transportation benefits of walkable suburbs; and emphasized the need for future research on New Urbanism (Talen, 2019). It will be important to address these needs in future New Urbanist projects.

Overall, the trajectory of New Urbanism from its inception to date, which is reflected in its resilience and expansion in the face of development trends of the 1990s, and later in its impact on development projects, policies, and regulations, suggests that the paradigm will continue to evolve and influence development practices in the United States with or without the label. While the founding members of New Urbanism continue to be prominent practitioners and protagonists of the movement, professionals in early years of their career have been organizing themselves as the 'Next Generation of New Urbanists' to address current and future challenges of development (Wright, 2003). Further research is needed, however, on the benefits of New Urbanism in the context of contemporary circumstances of development especially in the post-COVID-19 world.

\section{Acknowledgments}

The author would like to thank the anonymous reviewers and the editors of this thematic issue for their helpful suggestions.

\section{Conflict of Interests}

The author declares no conflict of interests.

\section{References}

Audirac, I., \& Shermyen, A. (1994). An evaluation of neotraditional design's social prescription: Postmodern placebo or remedy for suburban malaise? Journal of Planning Education and Research, 13(3), 161-173.

Badger, E. (2020, March 24). Density is normally good for us. That will be true after coronavirus, too. The New York Times. Retrieved from https://www.nytimes. 
com/2020/03/24/upshot/coronavirus-urban-

density-risks.html

Bhattarai, A. (2020, May 7). Neiman Marcus files for Chapter 11 bankruptcy. The Washington Post. Retrieved from https://www.washingtonpost.com/ business/2020/05/07/neiman-marcus-bankruptcychapter11

Boarnet, M. (2011). Longer view: A broader context for land use and travel behavior, and a research agenda. Journal of the American Planning Association, 77(3), 197-213.

Boarnet, M., Forsyth, A., Day, K., \& Oakes, M. (2011). The street level built environment and physical activity and walking: results of a predictive validity study for the Irvine Minnesota Inventory. Environment and Behavior, 43(6), 735-775.

California Air Resources Board. (n.d.). Priority population investments. California Air Resources Board. Retrieved from https://www.arb.ca.gov/cc/ capandtrade/auctionproceeds/community investments.htm

Calthorpe, P. (1993). The next American metropolis: Ecology, community, and the American dream. New York, NY: Princeton Architectural Press.

Calthorpe, P., \& Fulton, W. (2001). The regional city: Planning for the end of sprawl. Washington, DC: Island Press.

Carlton, J. (2020, May 3). Coronavirus offers a clear view of what causes air pollution. The Wall Street Journal. Retrieved from https://www.wsj.com/articles/ coronavirus-offers-a-clear-view-of-what-causes-airpollution-11588498200

Cervero, R., \& Kockelman, K. (1997). Travel demand and the 3Ds: Density, diversity, and design. Transportation Research Part D: Transport and Environment, 2(3), 199-219.

Congress for the New Urbanism. (2004). Codifying New Urbanism: How to reform municipal land development regulations. Chicago, IL: APA Planning Advisory Service.

Congress for the New Urbanism. (2018). Inclusion statement: Board statement on inclusion. Congress for the New Urbanism. Retrieved from https://www.cnu. org/inclusion-statement

Congress for the New Urbanism. (n.d.). The charter of the New Urbanism. Congress for the New Urbanism. Retrieved from https://www.cnu.org/who-weare/charter-new-urbanism

Day, K. (2003). New Urbanism and the challenges of designing for diversity. Journal of Planning Education and Research, 23(1), 83-95.

Delsohn, G. (1994). Peter's pockets. Planning, 1994(February), 18-21.

Dillon, L. (2020, April 26). Building dense cities was California's cure for the housing crisis. Then came coronavirus. Los Angeles Times. Retrieved from https://www.latimes.com/homeless-housing/story/ 2020-04-26/coronavirus-density-cities-urbanization- housing-climate-change

Duany, A., \& Plater-Zyberk, E. (1991). Towns and townmaking principles. New York, NY: Rizzoli.

Ellis, C. (2002). The New Urbanism: Critiques and rebuttals. Journal of Urban Design, 7(3), 261-291.

Ellis, C. (2019). Theoretical foundations. In E. Talen (Ed.), A research agenda for New Urbanism (pp. 8-19). Northampton, MA: Edward Elgar.

Ewing, R. H., Bartholomew, K., Burden, D., Cloyton, H. J., Brown, L., \& Ebrary, I. (2013a). Pedestrian- and transit-oriented design. Washington, DC: Urban Land Institute.

Ewing, R., Greenwald, M. J., Zhang, M., Bogaerts, M., \& Greene, W. (2013b). Predicting transportation outcomes for LEED Projects. Journal of Planning Education and Research, 33(3), 265-279.

Forsyth, A. (2015). What is a walkable place? The walkability debate in urban design. Urban Design International, 20(4), 274-292.

Franck, T. (2018, August 28). Under 'Amazon effect' retailers could be more exposed to supply shocks. CNBC. Retrieved from https://www.cnbc.com/2018/ 08/28/under-amazon-effect-retailers-could-bemore-exposed-to-supply-shocks.html

Frey, W. (2018). The millennial generation: A demographic bridge to America's diverse future. Brookings. Retrieved from https://www.brookings.edu/ research/millennials

Fry, R. (2020). Millennials overtake baby boomers as America's largest generation. Pew Research Center. Retrieved from https://www.pewresearch.org/facttank/2020/04/28/millennials-overtake-babyboomers-as-americas-largest-generation

Fulton, W. (1996). The New Urbanism: Hype or hope for American communities? Cambridge, MA: Lincoln Institute of Land Policy.

Fulton, W. (2017). The 'New Urbanism' movement might be dead. Governing. Retrieved from https:// www.governing.com/columns/urban-notebook/govnew-urbanism.html

Garde, A. (2004). New Urbanism as sustainable growth? A supply side story and its implications for public policy. Journal of Planning Education and Research, 24(2), 154-170.

Garde, A. (2006). Designing and developing New Urbanist projects in the United States: Insights and implications. Journal of Urban Design, 11(1), 33-54.

Garde, A. (2008). City sense and suburban design: Planners' perceptions of emerging suburban form. Journal of the American Planning Association, 74(3), 325-342.

Garde, A. (2009). Sustainable by design? Insights from U.S. LEED-ND pilot projects. Journal of the American Planning Association, 75(4), 424-440.

Garde, A. (2019). The future of urbanism. In E. Talen (Ed.), A research agenda for New Urbanism (pp. 153-165). Northampton, MA: Edward Elgar.

Garde, A., \& Kim, C. (2017). Form-based codes for zon- 
ing reform to promote sustainable development: Insights from cities in Southern California. Journal of the American Planning Association, 83(4), 346-364. https://doi.org/10.1080/01944363.2017.1364974

Gardiner, B. (2020). Pollution made COVID-19 worse. Now, lockdowns are clearing the air. National Geographic. Retrieved from https://www.national geographic.com/science/2020/04/pollution-madethe-pandemic-worse-but-lockdowns-clean-the-sky

Gose, J. (2012, November 27). Regulatory break for mixed-use projects. The New York Times. Retrieved from https://www.nytimes.com/2012/11/28/ realestate/commercial/mixed-use-developmentsget-regulatory-break-from-fha.html

Grant, J. L. (2006). Planning the good community: New Urbanism in theory and practice. New York, NY: Routledge.

Grant, J. L. (2007). Two sides of a coin? New Urbanism and gated communities. Housing Policy Debate, 18(3), 481-501.

Grosman, L. (2018). What the Amazon effect means for retailers. Forbes. Retrieved from https://www. forbes.com/sites/forbescommunicationscouncil/ 2018/02/22/what-the-amazon-effect-means-forretailers/\#481918822ded

Hamidi, S., Sabouri, S., \& Ewing, R. (2020). Does density aggravate the COVID-19 pandemic? Journal of the American Planning Association, 86(1), 495-509.

Hartung, A. (2017). Why the 'Amazon effect' is so huge in the USA, and not in other countries. Forbes. Retrieved from https://www.forbes.com/sites/ adamhartung/2017/05/31/why-the-amazon-effectis-so-huge-in-the-usa-and-greater-than-in-othercountries/\#759082b5aaef

Harvey, D. (1997). The New Urbanism and the communitarian trap. Harvard Design Magazine, 1997(1). Retrieved from http://www.harvarddesign magazine.org/issues/1/the-new-urbanism-and-thecommunitarian-trap

Henaghan, J., \& Rouse, D. (2018). Preparing for autonomous vehicles. Planning. Retrieved from https://www.planning.org/planning/2018/apr/ thecommissioner

Hirt, S. A. (2009). Premodern, modern, postmodern? Placing New Urbanism into a historical perspective. Journal of Planning History, 8(3), 248-273.

Institute of Transportation Engineers. (2017). Implementing context sensitive design on multimodal thoroughfares: A practitioner's handbook. Washington, DC: Institute of Transportation Engineers. Retrieved from https://environment.transportation. org/pdf/context_sens_sol/ir-145-e.pdf

Irvine, N. (2020). It's the end of world economy as we know it. The New York Times. Retrieved from https://www.nytimes.com/2020/04/16/upshot/ world-economy-restructuring-coronavirus.html

Jackson, A. (2019). Cultural competency and racial inclusion. In E. Talen (Ed.), A research agenda for New
Urbanism (pp. 81-107). Northampton, MA: Edward Elgar.

Katz, P. (1994). The New Urbanism: Toward an architecture of community. New York, NY: McGraw-Hill.

Kickert, C. (2019). Retail. In E. Talen (Ed.), A research agenda for New Urbanism (pp. 35-48). Northampton, MA: Edward Elgar.

Kotkin, J. (2020, April 26). Angelenos like their singlefamily sprawl. The coronavirus proves them right. Los Angeles Times. Retrieved from https://www. latimes.com/opinion/story/2020-04-26/coronaviruscities-density-los-angeles-transit

Maheshwari, S. (2020, July 5). With department stores disappearing, malls could be next. The New York Times. Retrieved from https://www.nytimes.com/ 2020/07/05/business/coronavirus-mallsdepartment-stores-bankruptcy.html?action=click \&module=Top\%20Stories\&pgtype=Homepage

Marshall, W. (2019). Transportation. In E. Talen (Ed.), A research agenda for New Urbanism (pp. 49-62). Northampton, MA: Edward Elgar.

Moore, S. M. (2013). What's wrong with best practice? Questioning the typification of New Urbanism. Urban Studies, 50(11), 2371-2387.

Myers, D. (2016). Peak millennials: Three reinforcing cycles that amplify the rise and fall of urban concentration by millennials. Housing Policy Debate, 26(6), 928-947.

Nelson, A. (2018). Connected. Planning. Retrieved from https://www.planning.org/login/?next=/planning/ 2018/may/connected

Nisenson, L. (2018). Best-case scenario planning. Planning. Retrieved from https://www.planning.org/ login/?next=/planning/2018/may/bestcasescenario

Oldenburg, R. (1989). The great good place. New York, NY: Marlowe \& Company.

Parolek, D. G., Parolek, K., \& Crawford, P. C. (2008). Formbased codes: A guide for planners, urban designers, and developers. Hoboken, NJ: John Wiley \& Sons.

Passell, A. (2013). Building the New Urbanism: Places, professions, and profits in the American metropolitan landscape. New York, NY: Routledge.

Payton, N. (2020). Thoughts about urbanism and architecture in the face of COVID-19. Congress for the New Urbanism. Retrieved from https://www. cnu.org/publicsquare/2020/08/03/thoughts-abouturbanism-and-architecture-face-covid-19

Robbins, E. (1998). The New Urbanism and the fallacy of singularity. Urban Design International, 3(1), 1-10.

Rouse, D. C., Henaghan, J., Coyner, C., Nisenson, L., \& Jordan, J. (2018). Preparing communities for autonomous vehicles. Chicago, IL: American Planning Association. Retrieved from https://www.planning. org/publications/document/9144551

Sanburn, J. (2018). Why the death of malls is about more than shopping. Time. Retrieved from http:// time.com/4865957/death-and-life-shopping-mall

Schlossberg, M., \& Brown, N. (2004). Comparing transit- 
oriented development sites by walkability indicators. Transportation Research Record: Journal of the Transportation Research Board, 1887(1), 34-42.

Smart Growth Network. (2006). This is smart growth. Washington, DC: Smart Growth Network. Retrieved from https://www.epa.gov/smartgrowth/smartgrowth-publication

Southern California Association of Governments. (2020). Demographics and growth forecast. Los Angeles, CA: Southern California Association of Governments. Retrieved from https://www.connectsocal. org/Documents/Adopted/fConnectSoCal_ Demographics-And-Growth-Forecast.pdf

Southworth, M. (1997). Walkable suburbs? An evaluation of neotraditional communities at the urban edge. Journal of the American Planning Association, 63(1), 28-44.

Steuteville, R. (1998). Traditional neighborhood development projects in the U.S. New Urban News, 1998(September/October).

Talen, E. (1999). Sense of community and neighborhood form? An assessment of the social doctrine of New Urbanism. Urban Studies, 36(8), 1361-1379.

Talen, E. (2005). New Urbanism and American planning: The conflict of cultures. London: Routledge.

Talen, E. (2019). A research agenda for New Urbanism. Northampton, MA: Edward Elgar.

The New York Times. (2020, July 13). Coronavirus in the U.S.: Map and case count. The New York Times. Retrieved from https://www.nytimes.com/ interactive/2020/us/coronavirus-us-cases.html

Trudeau, D. (2016). Tracing New Urbanism's suburban intervention in Minneapolis-St. Paul. Journal of Planning and Education Research, 38(1), 25-38.

Turner, V. K. (2019). Green New Urbanism. In E. Talen (Ed.), A research agenda for New Urbanism (pp. 63-80). Northampton, MA: Edward Elgar.

U.S. Census Bureau. (2017). Population estimates, July 1, 2017. U.S. Census Bureau. Retrieved from https://www.census.gov/quickfacts/fact/table/US/ PST045217

U.S. Environmental Protection Agency. (n.d.). Smart growth. U.S. Environmental Protection Agency. Retrieved from http://www.epa.gov/smartgrowth/ topics/eb.htm

U.S. Green Building Council. (2007). Pilot version: LEED for neighborhood development rating system. Washington, DC: U.S. Green Building Council. Retrieved from https://www.usgbc.org/ShowFile. aspx?DocumentID $=2845$

World Health Organization. (n.d.). WHO Coronavirus disease (COVID-19) dashboard. World Health Organization. Retrieved from https://covid19.who.int/ ?gclid=CjOKCQjwzbv7BRDIARIsAM-A6-3H4Yta9ygoe 3pBDxNOhM36prVKmlosIOrc384xDMrXz7sFh0KojZ saAla3EALw_wcB

Wright, B. (2003). The next generation of New Urbanists. Planetizen. Retrieved from https://www.planetizen. com/node/99/next-generation-new-urbanists

Wu, X., Nethery, R. C., Sabath, M. B., Braun, D., \& Dominici, F. (2020). Exposure to air pollution and COVID-19 mortality in the United States: A nationwide crosssectional study. https://dx.doi.org/10.1101\%2F2020. 04.05.20054502

\section{About the Author}

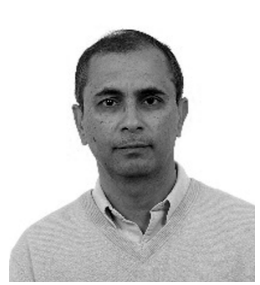

Ajay Garde (PhD) is an Associate Professor in the Department of Urban Planning and Public Policy at the University of California, Irvine, USA. His research and teaching focuses on the physical, environmental, and social problems related to the planning and design of the built environment. 